\title{
Besinning oor die teologiese ensiklopedie van Kuyper met Kerkreg en Diakoniologie as parameters
}

\author{
Bouke Spoelstra \\ Dept. Diakoniologie \& Missiologie \\ Potchefstroomse Universiteit vir $\mathrm{CHO}$ \\ POTCHEFSTROOM
}

\begin{abstract}
Abrahain Kuyper of the Netherlands compiled an extensive encyclopaedia or structure in which the unity of theology as well as the diversity of subjects was given account for. Contemporary theological trends and developments prove the fact that the process by which theologv is defined, its unity established, and by means of which subsidiary disciplines gain aufonomy, is largely uncxplored. Bu means of reference to two closely related subjects, the one more "theoretical' and the other more 'practical', this fact is clearly demonstrated. In conclusion the article sugrests that theologians should reconstuct the house of theology as a science by paying scholarly attention to basic theories, different presuppositions among theologians and the criteria by which both the unity and the diversity in theology are determined.
\end{abstract}

\section{INLEIDING}

Die vereniging van die Nederduits Gereformeerde Kerken uit die Doleansie met die Christelike Gereformeerde Kerk van Nederland presies 'n eeu gelede is al rede genoeg om een of ander onderwerp oor Abraham Kuyper, die 'Geweldige' (1837-1920), die lig te laat sien. Sy driedelige werk Encyclopaedie der Heilige Godgeleerdheid $(1908,1909)$ getuig van sy wetenskaplike maar ook dikwels intuitiewe gees waarmee hy die universele sowel as die kleinste detail mee kon hanteer (Rullman, 1925:545). Die onderwerp is ook aktueel omdat die vorige Sinode van die GKSA deputate benoem het om na die huidige teologiese ensiklopedie te kyk (GKSA, 1991:772-779). Daar verskyn min werke wat oor die teologiese ensiklopedie besin en sommige van die meer resente werke dek nie die problematiek wat in hierdie artikel aangesny word nie (vgl. Heyns \& Jonker, 1974; Eybers, et al., 1982).

Diakoniologie en Kerkreg word as parameters geneem omdat Kuyper die sprekende naam diakoniologie teenoor die term praktiese teologie uit die Skriftuurlike begrip diakonia geskep het (1909 III:472) en hy met die kriterium kerk bedoel het om kerkreg van sy ondergeskikte posisie ten opsigte van praktiese teologie te red (1909 III:213). In hierdie opsig verskil hy doelbewus van Kant en Schleiermacher. Hierdie studie sal die moontlikheid opper dat Kuyper as kind van die 19de eeu tog onbewus in belangrike 
opsigte by Kant en Schleiermacher aansluit (vgl. Spoelstra, 1991 b:209 e.v).

\section{PROBLEEMSTELLING}

Die vakwetenskaplike indeling van teologie dateer eers van 'n later datum en begin waarskynlik toe kerkgeskiedenis teen 1583 afsonderlik benader is (Pannenberg, 1976:400; vgl. Weber, 1959:79 i.v.m. dogmatiek en etiek). Die begrippe kerkreg en praktiese teologie kom aan die begin van die 19de eeu pertinent by Schleiermacher na vore (Schleiermacher, 1968:15 e.v; Pannenberg, 1976:351 e.v., 372 e.v; Bakker, 1990:20 e.v). Daarna het die $19 \mathrm{de}$-eeuse teologie in 'n "stroomversnelling" beland (Schulze, 1981:5.e.v., 31 e.v.). Die rasionalisme het hierin baie duidelik 'n rol gespeel.

Dit lyk asof verskillende faktore in die afgelope paar dekades stilweg besig is om ingrypende verandering in die teologiese ensiklopedie aan te bring. Sekere vakke raak geleidelik gedevalueer terwyl ander sonder wetenskaplike verantwoording, indien die onderwerp net nuttig en 'prakties' lyk en belangstelling gaande maak, summier vakstatus in die teologiese ensiklopedie kry.

Sommige teoloë in Europa verdeel die ontwikkeling van die teologie ewolusionêr in 'n mitiese, ontologiese en funksionele (praktiese?) fase. Die ontologiese fase het verbygegaan. Gevolglik word byvoorbeeld die bestaansreg van 'sistematiese teologie' vandag betwyfel, omdat dit tot die verbygegane ontologiese fase sou behoort (vgl. Smalbrugge, 1991:92). So 'n benadering raak nie net die bestaan en wese van vakke soos dogmatiek nie, maar bring eintlik die teologiese grondslae van elke vak en van die teologie in geheel in gedrang.

'n Mens kry die idee dat sommige teoloë die tradisionele gereformeerde teologie argief toe skuif. Dit geld veral vir leerstellige teologie. Heitink praat van spanning wat "oploopt naarmate die traditie opgaat in leerstelligheid en het karakter aanneemt van een systeem, dat van buitenaf wordt opgelegd, terwijl tegelijkertijd mensen verzuchten: ... het raakt me niet" (Heitink, 1990:206). In die post-Christelike era benader mense die teologie al meer pragmaties. Die eertydse woorde oor God word al meer woorde oor die mense. Die teo-logie word al meer antropo-logie. Hierdie tendens korrespondeer met die moderne strewe na kursusse, tegnieke en programme wat ook die soeke na 'n 'New Age' motiveer as "a hybrid mix of spiritual, social and political forces ... and it encompasses sociology, theology, the physical sciences, medicine, anthropology, history, the human potentials movement ..." (Chandler, 1989:17,23,33). Die tendens om teologiese, sosiologiese, antropologiese, historiese en politieke faktore vanuit 'n universalistiese vooronderstelling te vermeng, kan aangedui word (kyk Pieterse, et al., 1991:64-85). Hierdie tendens dwing ons minstens om krities na die wetenskaplike opbou van die teologie te kyk. 
Die werklikheid van raakvlakke, die noodsaaklikheid van onderlinge hulp en samewerking tussen teologiese dissiplines word vrywel algemeen in werke oor die ensiklopedie erken (De Wet, 1982:48 e.v.). In hoeverre teoloë egter nog vakwetenskaplik in dieselfde fakulteit met mekaar ensiklopedies saamwerk, is ' $n$ ander vraag wat hier nie beantwoord kan word nie. Akademiese 'spesialisasie' bevorder nie harmonie en eenheid in die teologie nie. Onvoldoende vakdissiplinering bring terreinoorskryding en die gevaar van dubbelloopteologie na vore (vgl. Trimp, s.j:160), byvoorbeeld wanneer 'n kerkregtelike en 'n diakonioloog los van mekaar en selfs met verskillende vertrekpunte die diakonia sou beskryf. Dit is daarom gebiedend noodsaaklik dat die teologiese ensiklopedie aan wetenskaplike kriteria verantwoord word.

Pannenberg sê dat die proses waardeur "subsidiary theological disciplines gain autonomy is largely unexplored" (1976:363). Juis praktiese teologie ondervind moeite om sy deeldissiplines te definieer (Nel, 1987:26 e.v). Die deputate van die GKSA wat die ensiklopedie moet bekyk, het van verskillende reformatoriese teologiese fakulteite oor die wêreld hulle teologiese leerplanne aangevra. Hierdie leerplanne maak 'n redelike lukraak en ensiklopedies onverantwoorde indruk: 'n mens kry die indruk dat in die teologie nie moeite gedoen word om rekenskap te gee van duidelike wetenskaplike kriteria te gee waarmee 'vakke' afgebaken word nie. So het die ensiklopediese verwarring tussen kerkgeskiedenis en sendinggeskiedenis my al vroeër opgeval (Spoelstra, 1972).

Vandag is praktiese teologie die nuwe "inding" (Hendriks, 1987:1) ên onder dié noemer trek 'n 'vak' wat gemeentebou genoem word aandag (Heyns, 1988:14). Die vak word reeds by verskillende teologiese fakulteite aangebied. Die meeste groepeer die vak onder praktiese teologie, terwyl die Teologiese Universiteit van Kampen (Broederweg) dit skynbaar onder ekklesiologie plaas (vgl. Te Velde, 1989). Ek kon tot nog toe nie 'n wetenskaplike ensiklopediese verantwoording vir 'n vak gemeentebou raakloop nie. Indien 'n vak gemeentebou bestaan, moet so 'n vak tog eintlik onder die ekklesiologie tuishoort. Gemeente hou immers verband met kerk en Nel sien 'n verband tussen die 'vak' en 'kerkreg' (vgl. Nel, 1987:32). Kamphuis wys op dieselfde verband en veral op die band tussen kerkreg en pastoraal (s.j:105). Verder kom die vraag op of ander sogenaamde 'praktiese' vakke (homiletiek, kategese ens.) nie ook op 'gemeentebou' gerig is nie. Vakke in die teologie vermeerder, maar basiese ensiklopediese vrae bly in die lug hang.

Wanneer die pastor al meer as 'n pastorale sielkundige beskou word, kom die teologiese status van 'praktiese teologie in die gedrang. Die blote feit dat 'n begeleier ' $n$ predikant is, maak die begeleiding nog nie bediening nie en kan ook nie die teologiese karakter van die vak of vakgroep bepaal nie. Publikasies wek egter die indruk dat iets wat met die predikant of kerk te doen het soms summier onder die noemer praktiese teologie tuisgebring word (vgl. Smuts, 1986 en De Jongh van Arkel, 1986). Praktiese teologie worstel enersyds om wetenskap en tweedens om teologiese wetenskap te bly 
(Jonker, 1968:6,16; König, 1982:22; Dreyer, 1991).

Maar ook kerkreg voer' $n$ stryd om as teologiese wetenskap aanvaar te word. Prof. Pillay van UNISA het die Kerkhistoriese Werkgemeenskap van Suid-Afrika in Januarie 1991 te Pretoria meegedeel dat Engelse en swart teoloë nie in kerkreg belangstel nie. 'n Mens hoor soms dieselfde geluid onder gereformeerde predikante.

Aan die ander kant bly die juris Sohm se siening immergroen wanneer hy op grond van Luther se twee-rykeleer betoog dat wat hy as juris onder kerkreg verstaan, met die geestelike wese van die kerk in stryd is (Sohm, 1892:27, 160, 695, 700; Bakhuizen van den Brink, 1968:20 e.v., 36; Bakker, 1990:13 e.v.). Hy het natuurlik gelyk wanneer en waar die kerk as 'n genootskap en kerkreg in terme van die sekulêre verenigingsreg verstaan word. Met die verenigingsreg val die kerkreg as nie-teologiese vak in positiewe reg vas (vgl. Smit, 1985:38). Die vraag is of die aksent op kerk of reg val. Kerk-reg kan met die Skrif as norm teologies beoefen word (Kuyper, 1909 III:206-240).

Kerkreg en praktiese teologie dien dus telkens as goeie parameters om te illustreer hoe die teologie sonder duidelike kenteoretiese norme en kriteria in verwarring raak. By Kuyper kom pastoraal op kerkregering (poimeniek, kubernetiek) neer (1909 1II:525). In 'praktiese teologie' lyk dit dikwels asof die 'pastor' al meer op grond van sy akademiese vorming as 'n kerkpsigoloog, begeleier of hulpverlener ten dienste van 'lidmate' aangedien word (vgl. Trimp s.j:150; Jonker, 1968:6; Bolewski, 1969:82; Douma, s.j:10).

Die term diakoniologie het besondere verdienstes (Trimp, s.j.:150 e.v.; Van der Walt, 1980:20). ' $n$ Naam kan egter nie ' $n$ vak bepaal nie en 'n duidelike wetenskaplike onderskeiding van diakoniologie teenoor praktiese teologie is nog nie gemaak nie. In hierdie studie word die terme diakoniologie en praktiese teologie min of meer as wisselvorme gebruik, omdat die benaming praktiese teologie wêreldwyd heers en selfs aan die Vrye Universiteit van Kuyper die benaming diakoniologie vervang het. Diakoniologie is egter ' $n$ besonder geskikte term om die bestudering van die dienste wat Christus ingestel het vanuit die Skrif saam te vat. Hiervoor moet Kuyper al die krediet kry (1909 II:588 e.v; III:47I e.v.).

Hierdie studie wil dus kortliks 'n paar kriteria uitlig waaraan teologie as wetenskap genormeer behoort te word. Daarna sal op 'n paar dominante teologiese motiewe in die 19de eeu gewys word voordat oorsigtelik na die teologiese ensiklopedie van Kuyper gekyk word. Op grond van die oorsig sal getrag word om enkele relevante konklusies te trek. Juis die kruispunt tussen relevante motiewe in die 19de eeu en die kriteria wat Kuyper gebruik om sy ensiklopedie in te deel, maak kerkreg en die sogenaamde praktiese teologie handige parameters om tendense in die teologiese ensiklopedie mee te illustreer. 


\section{NOODSAAKLIKE KRITERIA OM DIE TEOLOGIESE ENSIKLOPEDIE TE BEPAAL}

\subsection{Die aard van teologie}

Kuyper weet dat (veral sedert Kant) ontken word dat teologie wetenskap is en dat daar ook geen eenstemmigheid bestaan oor wat onder teologie verstaan moet word nie. Hy ag dit egter nie nodig om by die bepaling van die ensiklopedie op hierdie verskille in te gaan nie. Die verskille gaan grootliks oor wat as die voorwerp van die teologiese studie geneem word (Kuyper, 1908 I:46 e.v). Gevolglik is daar nie iets soos 'neutraliteit' in die beoefening van teologie nie. Sonder om enigsins afbreuk te doen aan grootse ensiklopediese werke wat ander gelewer het, moet die gereformeerde teoloog 'n definitiewe teologiese keuse uitoefen, sodat teologie noodwendig 'n bepaalde subjektiewe karakter dra (vgl. ibid:51 e.v.).

Hierdie feit moet deeglik verdiskonteer word waar teoloë uit verskillende 'skole' saam in teologiese werkgemeenskappe een of ander 'vak' beoefen. Reeds uit wat hierbo oor kerkreg en praktiese teologie gesê is, kan afgelei word dat daar nie iets soos een universele kerkreg of 'n gemeenskaplike praktiese teologie moontlik is nie.

Rome het byvoorbeeld alles wat die amp (hiërargie) in die Corpus iuris Canonici verorden, beskou as kerkreg wat van God kom. Op grond van sy absolute sola scriptura beginsel, het Luther die wetboek as pure aanmatigende menslike reg verbrand. Hy vereis dat die "Wortkönig" die kerklike praktyk en reg bepaal (Smit, 1985:41 e.v.; Van 't Spijker, 1990:86-90; Bakhuizen van den Brink, 1968:29). Sy teologie verskil dus radikaal van dié van Rome.

Aan die ander kant het Luther die sigbare kerk of preekinstituut onder sorg van die owerheid geplaas, terwyl die onsigbare kerk onder die regering van die Woord en Gees verkeer (Smit, 1985:29-38; vir Sohm is kerkreg contradictio in terminiis). Met sy vertrekpunt in 'n twee-rykeleer, verskil Luther op sy beurt weer ingrypend van Calvyn se teologie wat die onsigbare kerk in die sigbare gemeente onder leiding van die ampte beskryf (Calvyn, 1951:320(10), 331(1)). Die voorbeelde toon aan dat teologie 'n bepaalde karakter behoort te vertoon waarin 'skole' onderskei sal word op grond van basiese vertrekpunte.

Die bestudering van die openbaring van God behoort die algemene aard van teologie te tipeer (Jonker, 1968:15; Heyns \& Jonker, 1974:274 e.v.). Gevolglik word die Skrif as openbaring van God die principium theologiae ge noem (Kuyper, 1909 II:352 e.v.; Popma, 1946:70; Douma, s.j.:16; Heyns, 1974:127 e.v.; Stoker, 1961:73, 138 e.v.; Van der Walt, 1980:24). Sonder die Skrif kan die drie-enige God nie geken word en geen teologie (woorde oor God) wetenskaplik beoefen word nie. 
Soos verder aan aan die lig sal kom, verplaas Schleiermacher die openbaring van God en die Skrif as voorwerp van teologiese ondersoek met die fenomeen van religieuse ervaring. Hierdie ervaring kom as algemene fenomeen in die kerk voor sodat teologie eintlik in 'n breë ekklesiologie of godsdienswetenskap (Honig, 1925:87) opgaan. Die Skrif as afgeslote openbaring en as principium theologiae verleen aan die gereformeerde teologie 'n radikaal anjer aard as die aard van teologieë wat die religieuse mens of kerk as teologiese beginsel neem.

\subsection{Teologie vorm 'n eenheid binne 'n groter wetenskapgeheel}

Teologie begin in die Vroeë Christendom as 'n "practical science directed towards God" (Pannenberg, 1976:234, vgl. 231-240; Barnard, 1979/80:34). Selfs tot en met die Reformasie (kyk by Calvyn se Institusie) bied teologie "the total explication of Christian doctrine, proceeding by systematic methods and normative for exegesis" (Pannenberg, 1976:353 e.v). Die wetenskaplike nadenke het mettertyd vakindelinge nodig gemaak om ons te help verstaan. Daarom kom die vakindeling neer op "slechts hulplijntjes trekt" (Douma, s.j:19). Hierdie indeling het gelei tot "an ideological justification of the existing academic organisation" (Pannenberg, 1976:349 e.v.).

Die gangbare kompartementele spesialisasie op akademiese gebied verabsoluteer hierdie "hulplijntjes" sodat die "atomisering" van vakke ellendige gevolge vir die teologie as geheel inhou (De Wet, 1982:48 e.v.; vgl. Trimp, s.j.:160). Die teologie sou geweldig baat indien elke fakulteit op 'n gereelde basis die teologiese arbeid van die verskillende dissiplines onder mekaar sirkuleer om daarna in 'n simposium terugvoering te gee van hoe die resultate die verskillende vakgebiede onderling raak of beinvloed. Die feit dat teologiese kennis in vakke steriel ten opsigte van ander vakke bly lêe, moet teologie as geheel en sy waarde vir die praktiese kerklike lewe noodlottig tref.

Die teologie vorm as wetenskap deel van die totale wetenskaplike geheel of ensiklopedie (Kuyper, 1908 I:55; Stoker, 1961:245; Douma s.j.:10 e.v.). God het Hom immers primêr in die skepping en regering daarvan geopenbaar (NGB 2; Rom. 1:20). Teologie bied die kenbare omtrent die Skepper en sy werke en teologie behoort ook dieselfde vrugbare gesprek interfakultêr met ander vakwetenskappe te kan aanknoop. Die teologie is kragtens die eenheid in wetenskap verplig om sy ensiklopedie ook met die wetenskaplike kriteria te bepaal waarmee ander wetenskappe hulle indeling in vakgroepe, vakke en deeldissiplines verantwoord (Stoker, 1961:29 e.v., 29).

\subsection{Elke vak moet sy veld van ondersoek duidelik kan afbaken}

Wetenskap is so veel as moontlik gesistematiseerde en geverifieerde kennis wat verkry is langs die weg van verantwoorde metodes omtrent 'n bepaalde verskynsel of 
afgebakende veld van ondersoek (Stoker, 1961:50 e.v.). So kan 'n vakgebied, byvoorbeeld die Nuwe Testament, as afgebakende teologiese verskynsel, met eksegetiese, historiese en analitiese metodes ondersoek word. Op grond van hierdie ondersoekmetode kom vakke soos eksegese, openbaringsgeskiedenis en kanoniek tot stand. Ook die teologie moet dus presies kan aandui watter besondere verskynsel 'n bepaalde vak ondersoek of watter besondere metode aangewend word om die verkreë kennis in een bepaalde vak te orden. Die terreine tussen kerkreg en wat as gemeentebou aangedien word, is nog nie afgebaken nie en 'gemeentebou' mag gevolglik onder die bestaande ekklesiologie tuishoort. Dit mag verklaar waarom praktiese teologie swaar kry om sy deeldissiplines te definieer (vgl. Nel, 1987:26 e.v.): die naam dui nie werklik 'n bepaalde afgebakende veld van ondersoek aan nie. Die geloof in Christus waardeur ek gered word, is immers dogmaties en tegelyk baie prakties bepaald.

\subsection{Elke vak moet hom van sy perspektief of doel rekenskap gee}

Elke wetenskaplike baken vir hom 'n verskynsel in die voorwetenskaplike werklikheid af wat hy met 'n bepaalde doel gaan ondersoek. Hy gaan vanuit 'n doelgerigte perspektief binne daardie werklikheid te werk en hy moet daardie doel of bepaalde perspektief duidelik kan formuleer. Die vakwetenskaplike weet watter kennis hy wil versamel, verifieer en sistematiseer. Die doel en perspektief van die Afrikaanse taalkundige verskil radikaal van dié van die letterkundige, maar die twee verskillende vakke vul die kennis oor die Afrikaanse taal as bepaalde verskynsel aan. 'n Teoloog kan as doel stel om sy perspektief op kennis van 'n Bybelboek as sodanig (kanoniek), of van die presiese inhoud en betekenis van elke vers in terme van die geheel (eksegese), of van die deurlopende boodskap van die boek (openbaringsgeskiedenis) te rig.

Verskillende perspektiewe veroorsaak verskillende vakke, maar die gemeenskaplike veld van ondersoek bind die vakke onlosmaaklik in groepsverband saam. Die een steun op die ander. Elke perspektief vra sy eie metodes om by sy doel van wetenskap (geverifieerde en gesistematiseerde kennis van die verskynsel) uit te kom. So ontstaan vakke en vakfamilies. Elke vak kan ook weer op sy beurt vanuit verskillende perspektiewe ondersoek word (byvoorbeeld grondslae, geskiedenis of ontologie van die verskynsel) in welke geval die vak in deeldissiplines onderskei word wat deur die een vak saamgebind word.

\subsection{Elke vak of deeldissipline moet sy eie metodetegniek verantwoord}

Soms kan dieselfde verskynsel ook met twee verskillende verantwoorde metodes ondersoek word en wetenskaplike kennis omtrent dieselfde fenomeen aanvullend in twee of meer deeldissiplines van dieselfde vak weergegee word. Die geskiedenis van 
letterkunde verg een en die beskrywing 'n ander metode. Soms veroorsaak die perspektief en metode saam afsondelike dissiplines. Kerkreg en kerkgeskiedenis gebruik vanuit verskillende perspektiewe verskillende metodes en vul mekaar aan in kennis oor die ekklesia. Resultate met die induktiewe metode verkry, verskil van resultate wat met 'n deduktiewe metode verkry is (vgl. Stoker, 1961:253; Unisa, 1976:6, 30 e.v.; Spoelstra, 1992). Weer eens is dit nie maklik om die hele aantal heterogene deeldissiplines wat die praktiese teologie of diakoniologie moet saamstel, in terme van perspektief of metode te definieer nie.

\subsection{Verantwoording oor eie basisteorieē (vooronderstellings)}

Elke wetenskap berus op basisteorieë of vooronderstellings (Stoker, 1961:33, 140 e.v., 244). Hierdie vooronderstellings bepaal 'n vakgebied en hoe die vakke binne die ensiklopedie van die wetenskap geplaas gaan word (Douma, s.j.:10; Stoker, 1961:33). Die basisteorieë kan selfs perspektiewe op die vak bepaal. "Theologie als Denkweise bezieht sich auf einen Kanon grundlegender aussagen ... Ohne Dogma gibt es keine Theologie" (Fischer-Barnicol, 1969:93). Gevolglik moet elke teoloog in elke vakgebied hom rekenskap gee van sy eie en sy gespreksgenote se vooronderstellings (Van 't Spijker, in Du Plooy, 1991:76).

Dit is opvallend hoe min van verantwoording oor basisteorieë tereg kom byvoorbeeld waar nagraadse studente skrywers in verhandelinge aanhaal. Die basisteorie van skrywers word eenvoudig behandel asof dit nie bestaan nie of op dieselfde vlak as dié van die student lê.

Die begrip praktiese teologie is gelaai met 'n vooronderstelling en bring dadelik die vraag na vore of 'prakties' 'n geldige norm of kriterium is om 'n wetenskaplike ondersoekveld in die teologie mee af te baken. Uit wat hier gaan volg, sal blyk dat die onderskeiding teorie en praktyk op basisteorieè van Kant en Schleiermacher steun. Kuyper aanvaar vir sy ensiklopediese indeling die kriteria Skrif en kerk wat uit die Skrif voortkom en dogma en amp wat op hulle beurt volgens hom uit die kerk opkom (1909 III:206-213, 355 e.v., 476 e.v.).

\section{DIE BRUIKBAARHEID VAN 'TEORIE' EN 'PRAKTYK' AS BASISTEORIE VIR TEOLOGIE}

\subsection{Die skeiding tussen teorie en praktyk}

Die Aufklärung-filosoof Immanuel Kant (1724-1804) het gesê dat wat oor die werklikheid gedink word (teorie) nie dieselfde is as die werklikheid self nie en dat die werklikheid verreweg die belangrikste is. Daar is 'n kloof tussen die redelike aktiwiteit 
(reinen Vernuft) en die werklikheid waaroor gedink word (vgl. Hoekstra, 1925:278-284; Dijkstra, 1980:46; Schulze, 1988:27). Tweedens het hy as rasionalis die bestaansreg van teologie as wetenskap ontken, omdat die objek (God) waaroor teologie dink, nie redelik omlyn of ondersoek kan word nie. Daarmee het Kant groot invloed uitgeoefen om 'n teenstelling tussen teologie (teorie) en kerk (praktyk) te veroorsaak (Popma, 1946:37). Die 'kerk' is 'n empiriese fenomeen wat prakties in die wêreld aanwesig is, maar 'teologie' is net teorie wat nie met die werklikheid van God ooreenkom nie (vgl. die deïsme van die Aufklärung).

\subsection{Schleiermacher skep die begrip praktiese teologie}

Friedrich Schleiermacher (1769-1834) is in sy jeug beïnvloed deur die piëtisme (Sommer, 1989:310 e.v.) en het daarna onder invloed van die rasionalisme van Kant gekom. Hy neem as principium theologia et cognoscendi vir teologiese ondersoek die godsdienstige ervaring van die individu en kerk (Pannenberg, 1976:314 e.v.; Kuyper, 1909 II:634). Die kerk is vir hom "eine Gemeinschaft in Beziehung auf die Frommigkeit" (Schleiermacher, 1968:20). Hy skei eintlik kerk en gemeente (Dombois, 1974:36) en soos vandag dikwels gebeur, is kerk vir hom die "Kirchenregiment" terwyl die "Kirchendienst" by die gemeente tuishoort. Omdat hy teologiese gestalte gee aan die wysgerige apriorie van Kant word hy die invloedrykste teoloog van die 19de eeu wat tot vandag in baie kringe die toneel oorheers (Pannenberg, 1976:304 e.v.; Schulze, 1981:41 e.v.; Honig, 1925:87; Kuyper, 1908 I:348, 356; 1909 II:631 e.v.).

Schleiermacher skuif die tradisionele aandag vir die Skrif as Godsopenbaring opsy, maar wys op die godsdienservaring wat alle mense het. In hierdie ervaring vind hy'n empiriese ondersoekveld vir die teologie as wetenskap. Hy onderskei ensiklopediese, filosofiese, historiese en praktiese teologie. Die filosofiese teologie is teorie, terwyl by die historiese teologie die eksegese, kerkgeskiedenis en tydgenootlike leer tuishoort. Die eintlike teologie is die praktiese teologie, "in dem man vom Begriff der Kirchenleitung ausgeht, klassifiziert und in gewissen Gruppen zusammengestelt werden" (Schleiermacher, 1968:15 e.v.; Kuyper, 1908:354). By die praktiese teologie behoort die "Grundsätzen des Kirchenregiments en Schlussbetrachtungen über die practische Theologie" (Honig, 1925:87). "Die Inhalt der praktischen Theologie erschöpft sich in der Theorie des Kirchenregimentes in engeren Sinne und in der Theorie des Kirchendienstes" (Schleiermacher, 1968:20). Schleiermacher maak die praktiese kerklike daad en die menslike godsdienservaring die vertrekpunt vir die teologie.

Dit is nie hier die plek om Schleiermacher volledig te evalueer nie. Hy hef in prinsipe die verskil tussen die Christelike en ander godsdienste op omdat almal op een of ander vorm van "schlechthinniges Abhänklichkeitsgefühl" berus. Sy teologie is in werklikheid 'n vorm van godsdienswetenskap. In navolging van Schleiermacher is 'teorie' en 
'praktyk', die leer (teorie) en die lewe (praktyk), in die teologie en kerklike lewe noodlottig geskei (Dijkstra, 1980:46; Schulze, 1988:27). Schleiermacher se invloed kan duidelik gesien word in die byeenkoms van die Wêreldraad van Kerke by Canberra in 1991 waar voorgangers van allerlei godsdienste saam opgetree het asof elkeen 'n eie vergestalting van die universele godsdiens is.

Vandag word die rasionalistiese dualisme tussen teorie en praktyk al meer verwerp (Janson, 1982:330 e.v.; Barnard, 1979/80:44-46). Daar word al meer ingesien dat alle menslike handeling op "experience of meaning" berus (Pannenberg, 1976:433). Sonder 'n teorie of idee sal mense kwalik iets sinvols doen.

Die verhouding tussen teorie en praktyk is nog nie uitgemaak nie en hoewel mense graag van prakties praat, is die "meaning of 'practice' not selfevident" (vgl. Pannenberg, 1976:435-438). Schleiermacher het onder die noemer praktiese teologie die weg gebaan vir 'n antroposentriese teologie. Heitink noem alle teologie "ervaringsteologie" wat weergee wat mense binne hulle eie situasie van God se koms deur sy Woord na die wêreld opvang. Hy lees spanning tussen die tradisionele Christelike tradisie (teorie?) en die "beleweniswèreld" (praktyk?) van die moderne mens (Heitink, 1990:206,208).

Teorie en praktyk kan dus nie as bruikbare kriteria vir die indeling van die teologiese ensiklopedie aanvaar word nie en kerkreg en diakoniologie moet nie 'n alternatiewe 'praktiese teologie' teenoor 'teoretiese' teologie probeer wees nie. Die valse probleemstelling tussen teorie en praktyk het teologie en geloof in botsing gebring (vgl. Du Plooy, 1991:73 e.v.), sodat daar vandag 'n geroep opgaan dat die teologie weer vromer en die praktyk weer wetenskapliker moet word, omdat die kloof tussen teorie en praktyk apokrief geword het (Bolewski, 1969:81).

\section{5. 'N OORSIG VAN KUYPER SE ENSIKI OPEDIE}

\subsection{Kuyper se Encyclopaedie der Heilige Godgeleerdheid}

In die magistrale driedelige werk $(1908,1909)$ bespreek Kuyper eers die naam, idee, begrip en geskiedenis van die ensiklopedie (deel I). Daarna behandel hy die organiese geheel van die wetenskap waarbinne die teologie hom bevind. Hy behandel die begrip en principium theologiae, die metode, organisme en geskiedenis van die teologie (deel II).

In die derde deel wil hy die geheel van die teologie logies orden volgens die kousale beginsel dat een groep ' $n$ mens bring tot waar die ander begin (1909 III:4). Hy neem die openbaring van God as vertrekpunt en identifiseer dit met die Heilige Skrif as testimonium Spiritus Sancti (1909 III:5 e.v.). Gevolglik plaas hy die bibliologiese vakgroep voorop, wat onderskei word in kanoniese, eksegetiese en pragmatiese vakke. 
Hy beweer dat die Skrif die 'wêreldkerk' voortbring en met verwysing na Schleiermacher stel hy die reg van die ecclessia om 'n eie groep teologiese vakke te vorm (1909 III:182-3). Hy stel dus die kerk direk na die Skrif sonder om te vra hoe die Skrif die kerk veroorsaak en wat 'kerk' in terme van die principium theologiae beteken.

Die ekklesiologiese vakgroep verdeel hy in institutêre en organiese vakke. Kuyper het allerlei vakonderskeidinge wat nie teologies burgerreg verkry het nie; ons bepaal ons slegs tot die vakke wat bekend is. Die institutêre vakke verdeel hy in diatetiese, historiese en statistiese vakke, waarvan eintlik net kerkreg (diatetiese vakke) en kerkgeskiedenis (historiese vakke) beoefen word.

In die logiese orde is die kerk vir Kuyper subjek van die dogma en vorm dogmatologie die derde vakgroep. Hy verdeel die dogmatologie in diatetiese, tetiese en antitetiese vakke. Onder eersgenoemde kom simboliek, dogmageskiedenis; onder tetiese vakke dogmatiek en etiek en onder antitetiese vakke polemiek, elenktiek en apologetiek te pas.

Die diakoniologiese groep vakke moet volgens sy logiese beginsel eintlik uit die dogma voortkom, 'n feit wat Kuyper nie toestem nie (1909 III:466). Hy ontleen die kriterium van amp per slot van rekening aan die 'kerk' wat beteken dat die kerk as instituut in Kuyper se taal ook die diakoniologie veroorsaak soos die dogma. Daarmee stel hy hom op die genootskaplike kerkregtelike standpunt. Ons kom later terug op die dualisme in verband met die basisteorie tusssen kerk en Christus by Kuyper. Hy verdeel die groep in didaskaliese vakke (homiletiek, kategetiek, liturgiek, prostetiek). presbiteriale vakke (poemeniek, kybernetiek), diakonale vakke (met ' $n$ minder bekende onderverdeling) en laïcale vakke (waarin Kuyper die kerk as organisme of as groep van gelowige mense tuisbring).

\subsection{Die Skrif as Kuyper se kriterium vir die eerste hoofvakgroep}

Dit is wenslik dat ' $n$ teologiese ensiklopedie hom eers sal verantwoord ten opsigte van 'n aantal basiese vakke soos kenteorie, die ensiklopedie self en prologomena met betrekking tot die teologie, sy relasie en gesprek met ander wetenskappe en moontlik selfs die hermeneutiek waarmee na die Skrif gegaan word. Kuyper het aan die behoefte in die eerste twee dele van sy Encyclopeadie der Heilige Godgeleerdheid probeer voldoen. Ons meen dit is noodsaaklik dat hierdie basiese behoefte in die teologiese ensiklopedie in 'n basiese vak wetenskaplik verantwoord word, voordat tot die bibliologiese vakke oorgegaan kan word.

Kuyper neem die openbaring van God as vertrekpunt (1909 III:50), maar identifiseer openbaring sito-sito met die Heilige Skrif. In die lig van artikel 2 NGB is dit 'n vraag of openbaring en Skrif sinoniem is. Die fundamentele plek wat Kuyper aan die biblio- 
logiese groep vakke teenoor die ander toeken, volg logies wanneer die Skrif die principium theologiae is. Al die teologiese vakke moet aan die Skrif genormeer word en daarom sal daar dikwels leenmateriaal uit die bibliologiese groep, byvoorbeeld eksegese, gebruik word. Kuyper noem herhaaldelik sy vier kriteria waarmee hy die teologiese vakke indeel: Skrif, Kerk, dogma en amp (1909 III:210, 356 e.v., 466-481).

\subsection{Die kerk as kriterium vir die tweede hoofgroep: ekklesiologie}

Kuyper het skerp waargeneem dat Schleiermacher op filosofiese gronde "de Theologie glippen laat en er de Ecclesiologie als voorwerp van onderzoek voor in de plaats schuift" (1909 I:349, 1909 III:347). Hoewel hy dit raaksien, plaas Kuyper selfs met verwysing na Schleiermacher, die 'kerk' onmiddellik na en naas die 'Skrif' as kriterium vir ensiklopediese indeling (1909 III:183 e.v.). Hy wen op Schleiermacher deur die Skrif voor kerk te plaas, maar skep 'n probleem vir die diakoniologie. Christus het immers dienste met die oog op die kerk gegee (Matt. 28:19, Rom. 10:14 e.v., Ef. 4:11 e.v.). Hy vra homself ook nie af of die Skrif primêr gegee is om die kerk of dalk die koninkryk daar te stel nie (vgl. Ridderbos, 1950:288). Loisy het immers net 'n paar jaar voor Kuyper se ensiklopedie verskyn het, beweer dat Christus die koninkryk gepreek het en dat sy dissipels daarvan die kerk gemaak het (Ridderbos, 1950:291).

Kuyper gee daarby aan die begrip van die sigbare kerk 'n formele betekenis van kerk "als instituut" teenoor kerk "als organisme" (1909 lll:204, 214 e.v.; vgl. Haitjema, 1951:7). Waar die kerk (ekklesia) in die Skrif en die gereformeerde belydenisskrifte altyd mense in organiese eenheid in Christus en met mekaar (d.w.s. organisme onder leiding van opsieners) is, sluit Kuyper se idee van die 'geinstitueerde kerk' aan by die kerkbegrip wat uit die 18 de eeu by Schleiermacher en in die Nederlandse Reglement van 1816 na vore getree het.

Hy plaas gevolglik die vak kerkreg voorop om die kerk as instituut te kan definieer. Kerkreg moet die "eigentlijke architectoniek van de Kerk als instituut" beskryf (1909 III:232) en so die "Verfassung der Kirche" bied (1909 III:239 e.v.) soos dit in die sinodaal-presbiteriale kerkinrigting verwesenlik word (ibid:240). Hy waardeer Schleiermacher se "Leitung und Führung der Kirche" as die korrekte vertrekpunt (1909 III:469). Die kerk as kriterium naas die Skrif is dus grootliks (soos by Schleiermacher) die sigbare en empiriese "Kirchenregiment", die kerk as regspersoon, "de Kerk als het vaste moment ... dat een historie doorloopt" (1909 III:261). "Het eenig juiste principium divisionis ligt daarom in de Kerk zelve, en wel, meer bepaald, in de Kerk als instituut" (1909 III:290).

Kuyper se onderskeiding van die kerk as instituut en die kerk as organisme (wat heeltemal 'n aparte verskynsel is, 1909 III:305-345), het diep ingeslaan by 20 ste-eeuse gereformeerdes (Runia, 1979:24 e.v.). Dié onderskeiding en skeiding bly nietemin 
hoogomstrede (Haitjema, 1951:7 e.v.; Kamphuis, s.j.:88; Bakker, 1990:15; Velema, 1991). Elders het ek aangetoon dat die Skrif, die NGB, artikel 30-32 en die Dordtse Kerkorde uit die 17 de eeu nie 'n presbiteriaal-sinodale kerkregeringstelsel ken nie, maar van presbiteriale kerkregering uitgaan (Spoelstra, 1989:17, 30 e.v., 113, 142-147).

Die uitgangspunt in 'n objektiewe 'kerk as instituut' is eie aan die genootskaplike of kollegialistiese kerkbegrip (Spoelstra, 1989:13 e.v.). Kuyper wou van Schleiermacher se subjektiwisme wegkom (1909 II:355 e.v.) en het waarskynlik daarom gehuiwer om sy vertrekpunt soos Rome en Calvyn in die geroepe dienaars, die biskoppe of presbiters, te neem en het dus die dienste in die vierde en laaste vakgroep geplaas (1909 III:524 e.v.). As hy die presbiters en nie die 'kerk as instituut' nie as kriterium vir sy tweede vakgroep geneem het, sou hy die diens van die dienaars (diakoniolgie) onmiddellik op die bibliologiese vakke moes laat volg het; hulle diens was immers die voorwaarde vir kerkvorming. Die evangelie moes immers geleer en gepreek word en gelowiges moes geglo het op grond van wat hulle van gestuurde dienaars gehoor het, voordat daar 'n kerk kon wees (Matt. 28:19; Hand. 1:8 e.v.; Rom. 10:14 e.v.) Die Skrif kon nie sonder verkondiging deur dienaars (soos Kuyper skynbaar aanneem) die kerk tot gevolg gehad het nie. Die 'dienste' wat hy onder diakoniologie tuisbring. het die Here gebruik om 'n kerk op 'n plek te vergader. Tussen openbaring en kerk moes eers verkondiging. opsig (Hand. 20:28) en sakramentbediening (Matt. 28:19) plaasvind, voordat daar van 'n kerk sprake kan wees.

Dit lyk dus asof minstens aspekte van diakoniologie logies en saaklik net na die bibliologie bestudeer moet word voordat ons die ekklesiologie aan die orde kan stel.

\subsection{Die dogma as kriterium vir die derde vakgroep}

Die ekklesiologie gaan seker logies aan die dogmatologie vooraf. Dogmatiek is vir Kuyper die binneste heiligdom van die teologie, "de ons geopenbaarde kennisse Gods" (1909 IIl:346 e.v.). Elkeen kan nie maar sy eie biblisistiese vertolking van die Skrif gee soos hy of sy wil nie. Die ecclessia vertolk die Skrif sodat die dogma voor ons lê (1909 II:587 en III:355). Die kerk is die subjek van die dogma wat in die derde vakgroep teologies ondersoek word.

Kuyper verbind etiek as tetiese vak aan dogmatiek (1909 III:362), terwyl die kerk tog nie die outeur van die etiek is soos in die geval van die dogma nie. Kamphuis wys byvoorbeeld op die intieme verband tussen kerkreg en etiek (s.j.:105). Aan die ander kant hou Weber (1959:82 e.v.) vol dat credenda en agenda nie geskei mag word nie. 'n Ruimer kriterium as dogma (soos geloof) mag die etiek as geloofsvertolking van die sedewet in die Skrif soos dit in 'n kerkgemeenskap lewe, natuurliker by die dogmatologie laat aansluit. 
Kuyper se 'antitetiese vakke' (polemiek, elenktiek en apologetiek; vgl. Kuyper, 1909 I1I:363-366) as deel van die dogmatologie oortuig ook nie. Sonder om op die probleem te probeer ingaan, kom die vraag op of elke aspek van die teologiese wetenskap nie geroepe is om uit eie vakdissipline die verdediging teen die pneuma tou kosmou (ibid:364) aan te bied nie. Basiese verantwoording, verdediging en propagering van geloof kom oor die hele spektrum van die teologie aan die orde. In die 'praktiese' beoefening van apologetiek en elenktiek is daar immers veel wat by die diakoniologie (insluitende missiologie) tereg moet kom.

\subsection{Die amp as kriterium vir die vierde groep teologiese vakke}

Kuyper erken eerstens dat die amp 'n instelling van Christus is (1909 II:587 e.v.) en dat Hy die ampsdraers gebruik. Kuyper beskou die amp egter ewe goed as orgaan wat uit die kerk voortkom en waardeur die kerk as instituut (buite die organisme om) werk. Hy praat van die "ecclesia instituta die tot deze verrichtingen roept" omdat die "empirisch bestaande Kerk" behoefte het aan "organen ... die haar leven leiden en richten konden", hoewel hy toegee dat die Hoof Christus die funksies moet (of behoort te) beheers (1909 III:468-471). Die Nuwe Testament ken egter nie 'n institusionele kerk as regspersoon wat sy eie ampte skep nie (Friedberg, 1965:13 e.v.) of soos Kuyper sê, as sy 'organe' gebruik nie.

Kuyper wil eintlik nie Christus met die kerk as instituut verplaas nie; hy hou rekening met die dienste deur wie Christus werk (1909 II:468, 473, 476). Hy stel egter die dienste net so veel of nog meer in diens van die kerk (1909 III:212,470, 476) en praat van die instituut wat hom van ampte bedien (ibid 213) terwyl hy ook sê dat Christus hom van die ampsdraers bedien (ibid 473). Kerk en Christus vorm feitlik wisselterme. Die anomalie tussen die amp waarvan Christus (vgl. Calvyn, 1889:616) of die amp waarvan die kerk as instituut hom bedien, probeer Kuyper versoen in 'n mistieke vereniging tussen Christus en die ampsdraers (1909 Ill:468-476; vgl. 210, 212-3).

Kuyper se werkwyse bring ook verdere anomalieë tot stand: hy ontken stellenderwys die reg om die studievakke wat op die amp betrekking het, onder die ekklesiologie te rangskik. Tog sê hy ook dat die kerkreg onder ekklesiologie die instelling en samestelling van die amp moet bestudeer en dat die diakoniologie hierdie "Lehnsätze" moet oorneem en daarmee op die metode van die diakonie moet toespits (1909 III:476 e.v.).

'n Mens hoor iets van Schleiermacher se aanvegbare skeiding tussen teorie en praktyk wanneer Kuyper sê dat die vierde vakgroep nie 'n beskoulike, maar 'n praktiese doel op die oog het. Hy sê dat deur middel van hierdie vakke ons onsself rekenskap gee van die wyse waarop ons met hierdie ampte verkeer het (1909 III:212). Iemand wat nie rasionalisties soos Kant teorie en praktyk skei nie, kan Kuyper hier nie glo nie, tensy 
diakoniologie geen selfstandige teologies-wetenskaplike dissipline is nie, maar net op die toepassing van ander teologiese vakke se resultate neerkom.

Kuyper oortuig nie dat die presbiteriale vakke (pastoraal of poimeniek en kybernetiek) in die diakoniologiese vakgroep weg van kerkreg in die ekklesiologie tuishoort nie (vgl. Kuyper, 1909 III:524 e.v.). Hyself koppel die presbiter een oomblik aan kerkregering en sorg, terwyl hy die presbiter ook aan kerkreg verbind en selfs van die persoonlike "regeeringstalent" melding maak (ibid:531). As die persoon regeer, het sy diens met kerkreg te doen. Ondertussen het ek elders aangetoon dat die presbiter, die pastor, die sin aan presbiteriale kerkreg verleen en daarom die hart van gereformeerde kerkreg tipeer (vgl. Spoelstra, 1991a; Spoelstra, 1989:16 e.v., 113, 143 e.v., 225 e.v.).

Indien die kerkregering die bediening (diakonia) van die presbiter as vertrekpunt neem, wil 'n mens die term kerkreg bevraagteken. Die benaming kerkreg klink na 'n deeldissipline van die reg soos privaatreg, maatskappyreg en ontlok dan tereg die kritiek wat Sohm (1892) uitgespreek het. Tweedens gebruik Kuyper die term kerkreg wat Schleiermacher geskep het, omdat hy 'n vaste kerk as instituut in plaas van 'n dinamiese kerk (organisme) as kriterium in sy ensiklopedie gebruik. Na my mening sou kybernetiek (kerkregering) 'n beter naam vir die huidige vak kerkreg wees. Aan die Teologiese Skool op Potchefstroom is die kerkorde (kerkregering) nog altyd onder kerkreg en nie onder diakoniologie nie behandel.

Kuyper plaas ook liturgiek (soos homiletiek) onder die didaskaliese vakke (dit wil sê behorende by die ampsbediening van die predikant). Tog sê Kuyper self dat liturgiek die wetenskap is wat die "theorie voor de kunst van den Cultus" en "vastgestelde vormen voor den openlijken eeredienst" bestudeer (1909 III:510 e.v.). Die definisie dui nie op ' $n$ besondere amp nie en pas nie by die betekenis wat Kuyper aan diakonia deur die amp toeken nie. In ' $n$ ander studie het ek aangetoon dat Barth die liturgie as basis vir die kerkorde neem en dat die oudste kerkordes van 1551 en 1554 inderdaad liturgie gereël het (Spoelstra, 1992b).

Onder gereformeerde teoloë bestaan konsensus dat die erediens op die ordelike ontmoeting van God en sy volk neerkom - 'n interpretasie waarmee Kuyper instem (ibid: 511,514 e.v.). Liturgiek verskil dus wesenlik van byvoorbeeld die homiletiek wat die diens van die predikant tydens 'n erediens bestudeer. Kuyper se plasing van liturgiek onder diakoniologie kan gevolglik nie gehandhaaf word nie, veral wanneer teoloe vandag tereg weer soos Calvyn (vgl. 1889:596 e.v.; Milner, 1970:133, 171) beklemtoon dat die kerk nie in die instituut (verenigingsreg) of amp (Rome) nie maar in die handelinge van mense-in-erediens sigbaar word (Van Aarde, 1989:470; Packstadt, 1992:114). Daarmee kom liturgiek in die sentrum van die ekklesiologie en buite die diakoniologie te staan. 
Dit is onduidelik hoe Kuyper sy principium theologiae (1909 II:355) in die Heilige Skrif kan stel en daarna die Skrif weer gelykwaardig met kerk, dogma en amp as kriterium kan gebruik vir sy ensiklopediese indeling. Sy vier kriteria (1909 III:358) is nie homogeen en nie gelykwaardig nie. Sy rasionele kategorieë kerk, dogma en amp, is nie aan die Skrif ontleen nie, terwyl hy die teologie daarvolgens indeel.

Daarby gebruik hy die begrip kerk as instituut wat bots met die betekenis van die ekklesia as gelowige mense in die Skrif. Hy gebruik die term amp, terwyl diakonia nie identies is aan amp of deur die Jode en Helleniste vir amp gebruik is nie. Inteendeel, Christus het die begrip diakonia met 'n eie inhoud gevul omdat dit ook 'n eie unieke funksie moes tipeer (vgl. Spoelstra, 1989:26-29).

Kuyper plaas die gelowiges wat in die Skrif en belydenis (Heid. Kat. S 21; NGB 27-32) die kerk is, in werklikheid buite die kerk en teologie. Van 'n ontplooiing van teologie rondom die "laicale" vakke (1909 III:547) kom by hom min of niks tereg nie. Die betrokkenheid van die gereformeerde kerke by maatskaplike, politieke en ekonomiese vraagstukke het in teologiese verantwoording problematies gebly.

Kuyper vertrou die kerklike aktiwiteit en inisiatief uitsluitlik aan 'ampsdraers' toe (ibid:548), Daarmee kom hy baie naby aan Schleiermacher se "clerical church" (vgl. Pannenberg, 1976:250 e.v., 428 e.v.). Gevolglik verras dit nie dat die kerke wat sterk in die Kuyper-tradisie beïnvloed is, anders as byvoorbeeld die Metodiste-kerke, worstel om die 'amp van gelowige' van die grond te kry en kan die passiewe rol wat in die kerk aan vroue toegeken word net met toelating tot die ampte van die 'kerk as instituut' hanteer word. Inisiatief is vir 'lidmate' nie beskore nie omdat die 'instituut' deur organe funksioneer en klerikaal en kollegiaal deur die kerkraad beheer word.

\section{KONKLUSIE}

Kuyper se magistrale ensiklopedie het groot invloed uitgeoefen, hoewel dit nie algemeen navolging gevind het nie. Barth het byvoorbeeld 'n baie eenvoudiger indeling van teologiese vakke voorgestel, naamlik eksegetiese, dogmatiese en praktiese vakke (vgl. Du Toit, 1973:1). So 'n indeling dek ook nie die vakindeling wat tans in teologiese fakulteite met 'n gereformeerde tradisie aangebied word nie.

Die deputate wat die ensiklopedie in opdrag van die Sinode van 1991 ondersoek, het die leerplanne van verskillende teologiese fakulteite in Suid-Afrika, Nederland en die VSA vergelyk. Hoewel dit nie die ensiklopedie verwoord nie, gee die vakindeling en vakbenaminge tog die indruk dat logiese opbou en verantwoording oor 'n teologiese eenheid of ensiklopdie ontbreek. Dit lyk ook asof ad hoc-aanpassinge en opname van 
los vakke soos gemeentebou maklik plaasvind.

Daar bestaan vandag 'n behoefte om die teologiese ensiklopedie wetenskaplik te verantwoord. Dit is veelseggend dat Heyns en Pieterse (1990) probeer om 'eerste treë' in 'n ou vak soos praktiese teologie te gee. Dreyer vra tereg indringende kenteoretiese vrae, waardeur die wetenskaplike sowel as die teologiese aard van die 'vak' nog steeds twyfelagtig bly (Dreyer, 1991:597-608). "Die vraagstelling raak dus nie primêr die verhouding tussen teorie en praktyk nie, maar lê verder terug op die vlak van meta- en basisteorieë" (Dreyer, 1991:598).

Ek is oortuig dat die teologiese ensiklopedie dringend 'n vakgroep benodig wat teologie vanuit 'n fundamentele of prinsipiële perspektief bestudeer. So 'n vakgroep moet oor begrippe soos teologie, die verhouding tot ander wetenskappe, basisteorieë, metodologie, hermeneutiek en daarom ook oor die verskillende vertrekpunte by verskillende 'skole' besin. Heyns en Pieterse (1990:4) ondersoek "mense se geloof in God en uitsprake oor God" onder die noemer teologie. Dreyer vind dit tereg nie goed genoeg nie en verwys na Velthuysen wat sê dat "bokonfessionaliteit" na "onkonfessionaliteit" lei (Dreyer, 1991:600). Dreyer wil die "unieke normatiewe betekenis van die Skrif" in teologie handhaaf (1991:602), terwyl Kuyper nooit Heyns en Pieterse se voorwerp van studie en openbaringlose definisie van teologie sou aanvaar nie. Sonder 'n behoorlike basiese teologiese vakgroep bly hierdie besinning lukraak rondskipper.

'n Wetenskaplike teologiese dissipline wat oor eie en ander vertrekpunte besin, is baie nodig of die neiging binne die Afrikaanse teologiese fakulteite sal toeneem om te veins (in byvoorbeeld werkgemeenskappe) dat almal dieselfde teologie beoefen of om mekaar te etiketteer (fundamentalisties, vrysinnig, histories-krities ens.). Dit is nodig om werklik wetenskaplik na mekaar te luister en basisteorieë uit te spel. Die reg om verskillende vooronderstellings te verklaar en te beoefen kan niemand betwis nie.

Daar is op die oomblik na my mening weinig ensiklopediese wisselwerking tussen die verskillende vakdissiplines binne dieselfde teologiese fakulteit en nog minder vind interfakulteitgesprekke plaas tussen teoloë met ander dissiplines aan dieselfde universiteit. Tog het die landswye werkgemeenskappe vir bepaalde vakgroepe 'n groot verandering gebring: daar het groter begrip en waardering vir mekaar gegroei. Tog betwyfel ek of daar al werklik na mekaar geluister en op mekaar geantwoord word. Die 'nuwe' Suid-Afrika mag, afgesien van universiteitsubsidies, die teologie verplig om wetenskaplik hande te vat en van mekaar te weet om te kan oorlewe.

Ek het elders al voorgestel om die teologie vanuit die openbaring en die koninkryk (die koningskap) van God in Christus te benader (Spoelstra, 1991b:222 e.v.). Ek bepleit dus 'n vakgroep in die teologiese ensiklopedie wat so 'n vertrekpunt moet en kan verantwoord. In groot kontoere en buitelyne kan die volgende vakgroepe deur die basiese vakgroep oorweeg word (vgl. Spoelstra, 1991b). 
- Met die openbaring van God as vertrekpunt volg onder die noemer Theologia Revelationis die bibliologiese vakgroep min of meer soos Kuyper dit angedui het.

* Die tweede vakgroep kan vanuit koninkryksperspektief die theologia regni of gubernationis Christi ondersoek. Hier moet primèr die dienste waardeur Christus in die wêreld werk aan die orde kom. Dit val op dat Heyns en Pieterse in navolging van Firet vir hulle praktiese teologie ook die koms van God in sy Woord tot die mens in sy wêreld raaksien (1990:54).

- Vakke soos kerkreg, missiologie en diakoniologie oorvleuel tans. Om van die openbaring van God na die mense wat die kerk is te kom, sal die leer van die dienste wat kerkreg tans bestudeer, saam met aspekte waarop diakoniologie fokus, herrangskik moet word.

- Diakoniologie vra baie keer dieselfde vrae as kerkreg oor die dienste (DKO deel 1). Verder sal waarskynlik met 'n vak soos kerugmatiek groter eenheid gebring moet word in die gestaltes van Woordbediening soos prediking (homiletiek), kategese, evangelisasie (sending) sowel as die cura specialis, die individuele pastoraat. Die openbare, besondere en individuele gestaltes van dieselfde Woordbediening is in hulle wese een, maar in hulle uitvoering verskillend. Hieroor is nog min navorsing gedoen.

* Daar is ruimte vir teologiese besinning oor die ekklesia waarby aspekte soos kerkregering, kerkorde, liturgie, sacerdotum ministerium (amp of diens van die gelowige) ter sprake kom. Die koninkryk moet egter die basis vir die ekklesia wees (Heid. Kat. S 48). Na 'n hergeformuleerde diakoniologie is daar plek vir ekklesiologie. Oor die algemeen heers daar vandag wêreldwyd groot verwarring oor wat die kerk is.

- In nou verband met voorgaande uitgangspunt (vgl. ook Spoelstra, 1991b:224) is daar ruimte vir die plasing van vakke wat die geloof bestudeer en wat die kerk tot kerk maak: hiermee word vakkke bedoel wat as theologia fidei die dogma, etiek, simboliek en byvoorbeeld die antitese met die New Age kan bestudeer. Teologiese studie behoort meer stelselmatig die verwarring van die eeu uit te wys en aan te toon op watter vooronderstellings en basisteorieë die strominge en selfs teologiese skole uiteengaan.

In een volsin is my gevolgtrekking dat die ensiklopedie van Kuyper vandag nog steeds die basis vorm van die teologiese ensiklopedie aan talle gereformeerde teologiese fakulteite in Suid-Afrika, Nederland en die VSA. Sy ensiklopedie het egter impotent geword om hedendaagse vrae te beantwoord. Om die wetenskaplike vrae van die teologiese ensiklopedie langer te ignoreer, mag pragmaties betaal, maar bewys die teo- 
logie as wetenskap geen guns nie. Dit is nodig dat gereformeerdes prinsipiële inisiatief neem en die vraagstukke rondom die teologiese ensiklopedie in behandeling neem.

\section{BIBLIOGRAFIE}

BAKHUIZEN VAN DEN BRINK, J.N. 1968. Ius Ecclesiasticum. Historische beschouwingen over Kerk en recht. Amsterdam : Noord-Hollandsche Uitgevers.

BAKKER, W. 1990. Geschicdenis van de wetenschap van het kerkrecht. (In Van 't Spijker, W., Van Drimmelen, L.C. red. Inlciding tot de studic van het kerkrecht. Kampen : Kok. p. 20-31.)

BARNARD, A.C. 1979/80. Dic historiesc ontwikkeling van dic Praktiese Teologic. (In Nel M., red., Dic Kerk se werk. Kongresreferate van die Werkgemeenskap vir Prakticse Teologie. p. 31-52.)

BOLEWSKI, H. 1969. Geschichtlichkeit der Predigt und Wissenschaftlichkeit der Theologie. (In Ncucnzeit, P. red., Die funktion der Theologie in Kirche und Gesellschaft. München : Kôsel p. 75-87.)

CALVYN, J. 1889. Institutic ofte Onderwijsinghe in de Christelijke Religie Vertaal deur Corsmannus, W. Doesburg : J.C. van Schenk Brill.

CALVYN, J. 1951. Die Inslitusie van Calvyn. Verkort wecrgegee deur A. Duvenage. Blocmfontein Sacum.

CHANDLER, R. 1989. Understanding the New Age. 2de Uilgawe. Dallas: Word Inc.

DE JONGH VAN ARKEL, I.T. 1986. Persoonlikhcid en ampsgeskikt heid van die predikant. Praktiese Teologie in Suid-Afrika, 1:24-38.

DE WET, J.I. 1982. Prakticse Teologic en Kerkgeskiedenis. (In Oberholzer, J.P. red., Dic kerk in dic wêreld. 'n Bundel opstelle. Pretoria : HAUM. p. 48-51.)

DIJKSTRA, H. 1980. Die aard van die persoonlike toespitsing van die heil in die Heidelbergsc Katcgismus ('n stcckprocf). In die Skriflig, 14(56):40)-53.

DOMBOIS, H. 1974. Das Recht der Gnade. Ockumenisches Kirchenrecht. Band II. Bielefeld : Lutherverlag.

DOUMA, J. s.j. Encyclopedic. (In Oricntatic in de Theologic. Studicgids samengesteld door de hongleraren aan de Theologische Hogeschool van de Geref. Kerken in Nederland te Kampen. Deventer : De Vuurbaak. p. 7-20.)

DREYER, T.F.J. 1991. Eerste trec in dic Prakticse Teologie - Waarheen? Hen omide Teologiese Studies, 47(3):597-608, September.

DU PLOOY, A. Ie R. 1991. Die aard en gesag van dic binding aan dic belydenisskrifte. In die Skriflig. 25(1):71-95, Maart.

DU TOIT, H.D.A. 1973. Voorwoord. (In Dic Kerk se werk. Kongresreferate van die Werkgemeenskap vir Prakticsc Tcologic. Pretoria : NHW-pers. p. 1-20.)

EYBERS, I.H., KÖNIG A. \& STOOP, J.A. red. 1982. Inleiding in die Tcologic (Derde hersiene en uitgebreide uitgawe). Preloria : NG Kerkbockhandel.

FISCHER-BARNICOL, H. 1969. Theologische Methode und mystische Erfahrung. (In Neuenzeit, P. Die Funktion der Theologie in Kirche und Gesellschaft. München : Kösel. p. 88-109.)

FRIEDBERG, E. 1\%5. Lehrbuch des katolischen und evangelischen Kirchenrechts. Frankfurt A.M : Minerva.

GKSA

Kyk

GEREFORMEERDE KERKE IN SUID-AFRIKA. 1991. Handelinge van die 44ste Nasionale Sinode van dic Gercformecrde Kerkc in Suid-Afrika. Potchefstroom : Admin. Buro.

HAITJEMA, T.L. 1951. Nederlands Hervormd Kerkrecht. Nijkerk : Callenbach.

HEITINK, G. 1990. Theologic en Psychologic: Ecn spanningsvcld. Gereforneerd Theologisch Tijdschrift, 90(4):206-220, November.

HENDRIKS, H.J. 1987. Teologies-prinsipiële begronding van "Gemeentebou". Praktiese Teologie in Suid-Afrika, 2:1-20.

HEYNS, J.A. \& JONKER, W.D. 1974. Op weg met die Teologie. Pretoria : NG Kerkboekhandel. 
HEYNS, L. 1988. Die plek van gemcentebou binne die Praktiese Teologic. Theologia Evangelica, 21(1):14-18.

HEYNS, L.M. \& PIETERSE, H.J.C. 1990. Eerste treč in dic Praktiese Teologic. Pretoria : Gnosis.

HOEKSTRA, T. 1925. Kant (Immanuel). (In Christ elijke Encyclopacdic voor het Nederlandsche Volk, Vol. 3:278-284. Kampen : Kok.)

HONIG, A.G. 1925. Schleiermacher (Friedrich Daniel). (In Christelijke Encyclopaedic voor het Nederlandsche volk, Vol. 5:86-88. Kampen : Kok.)

JANSON, M. 1982. Praktiese Teologic. (In Eybers, I.H., Konig, A., Stoop, J.A., red. Inleiding in die Tcologie. Pretoria : NG Kerkboekhandel. p. 325-346.)

JONKER, W.D. 1968. Theologie en praktijk. Een peiling van het theologisch karakter van de diakoniologische vakken. Kampen : Kok.

KAMPHUIS, J. s.j. Ekkiesiologic. (In Oriëntatic in de Theologic. Studicgids samengesteld door de hoogleraren van de Theologische Hogeschool van de Geref. Kerken in Nederland te Kampen. Deventer : De Vuurbaak. p. 88-107.)

KÖNIG, A. 1982. Teologie. (In Eybers I.H., König, A., Stoop, J.A., red. Inleiding in die Teologie. Pretoria : NG Kerkhockhandel. p. 1-44.)

KUYPER, A. 1908, 1909. Encyclopacdic der Heilige Godgelecrdheid. Dric dele. Kampen : Kok.

MILNER, B.C. 1970. Calvin's Doctrine of the Church. Leiden : Brill.

NEL, M. 1987. Dic verhouding van gemeentebou to dic ander dissiplines van dic vak Praktiese Teologic en ander teologiesc vakke. Pruktiese Teologie in Suid-Afrika, 2:26-37.

PACKSTADT, I. 1992. De liturgische beleving van de Zondag in de orthodoxc kerk. Tijdschnft voor Liturgie, 76(1/2):112-115, Januarie - Maart.

PANNENBERG, W. 1976. Theology and the Philosophy of Science. London : Darton, Longman \& Todd.

PIETERSE, H.J.C., SCHEEPERS, P.L.H. \& VAN DER VEN, J.A. 1991. Religious Beliefs and Ethnoccntrism. Joumal of Empinical Theology, 4(2):64-85.

POPMA, KJ. 1946. Calvinistische Geschiedbeschouwing. Francker : Wever.

RIDDERBOS, H. 1950. De komst van het koninkrijk. Kampen : Kok.

RULLMAN, J.C. 1925. Kuyper (Abraham). (In Christclijke Encyclopaedic van het Nederlandsche Volk, Vol. 3:538-548. Kampen : Kok.)

RUNLA, K. 1979. The Church and its Social Calling. (Is Reformed Ecumenical Synod 1980). Reports Grand Rapids : Intcrim Committce.)

SCHLEIERMACHER, F.D.S. 1968. Schleiermacher-Auswahl. Mit einem Nachwort von Karl Barth. red. Bollie H. München \& Hamburg: Siebenstern Taschenbuch Verlag.

SCHULZE, L.F. 1981. Tcologie in die stroomversnelling. Potchefstroom : Potchefstroomse Teologiese Publikasics.

SCHULZE, L.F. 1988. Dic Katcgismusprediking in dic krisis. In die Skriflig, 22(88):24-31.

SMALBRUGGE, M.A. 1991. De ondergang van de systematische Theologie. Kerk en Theologie, 42(1):28-41, Januaric.

SMIT, CJ. 1985. Kerkreg en Kerkorde in die lig van (jod se reg en orde vir sy kerk. Potchefstroom : PU CHO (Th.D Procfskrif).

SMUTS, A.J. 1986. Dic huwelik en gesinslewe van dic predikant. Praktiese Teologie in Suid-Afrika, 1:5268.

SOHM, R. 1892. Kirchenrecht. Deel I. Leipzig : Von Duncker \& Humblot.

SOMMER, W. 1989. Die Stellung Semler und Schleicrmacher 7u den reformatorischen Bekenntnisschriften. Kenugma und Dogma, 35(4):269-315, Okt/Dez.

SPOELSTRA, B. 1972. Kan Sendinggeskiedenis en Kerkgeskiedenis ensiklopedies geskei word? In die Skriflig, 6(23):45-53.

SPOELSTRA, B. 1989. Gereformecrde kerkrcg en kerkrcgering. Handboek by die Kerkorde. Hammanskraal : Tcologiese Skool.

SPOELSTRA, B. 1991a. Presbitcrianisme en dic presbiteriale kerkregering. Ned. Geref. Teologiese Tydskrif, XXXII(1):57-67, Maart.

SPOELSTRA, B. 1991b. Die plek van Kerkrcg en Diakoniologie (Praktiese Teologic) in dic teologiesc ensiklopedic. Praktiese Teologie in Suid-Afrika, 6(2):206-226. 
SPOELSTRA, B. 1992a. Dilcmma tussen Prakticse Tcologic en Ekklesiologic. Ongepubliseerde artikel.

SPOELSTRA, B. 1992b. Dic liturgic in dic ercdiens deur ou en nuwe oë bekyk. Ongepubliscerde referaat. Winterskool 30 Junic. PUCHO.

STOKER, H.G. 1961. Bcginsels en metodes in die Wetenskap. Potchefstroom : Pro Rege.

TE VELDE, M. 1989. Gcreformcerde gemeenteopbouw. Een eerste koersbepaling voor cen nicuw theologisch vak. Kamper Bijdrage, XXX:5-44.

TRIMP, C. s.j. Diakoniologie. (In: Oriëntatie in de Theologic. Studiegids samengesteld door de hoogleraren aan de Theologiesche Hogeschool van de Geref. Kerken in Nederland te Kampen. Deventer : De Vuurbaak. p. 146-164.)

VAN VUUREN, J.C.G. red. 1976. Oriëntering in die pedagogiek. Studieboekrecks nr. 3. Pretoria : Universiteit van Suid-Afrika.

VAN'T SPIJKER, W. 1990. De opvattingen van de Reformatoren. (In Van't Spijker, W., Van Drimmelen, L.C. red. Inleiding tot de studie van het Kerkrecht. Kampen : Kok. p. 86-103.)

VAN AARDE, A.G. 1989. 'n Nuwe-Test amentiese begronding van die ecnheid van die kerk en die eis om kerkeenheid vandag. Hervomde Teologiese Studies, 55(2):461-475.

VAN DER WALT, J.J. 1980. Die verhouding van die diakoniologie to dic ander tcologiese dissiplines. (In Nel, M. red. Dic kerk se werk. Kongresreferatc van dic Werkgemeenskap vir Praktiese Teologic. p. 20-30.)

VELEMA, W.H. 1991. Kuypers conceptie van de kerk als organisme kritisch bekeken. Theologia Reformata, 34(4):295-309, Desember.

WEBER, O. 1959. Grundlagen der Dogmatik. Neukirchen-Mors : Buchhandlung des Erziehungsvercins. 
